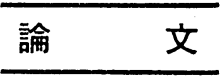

\title{
光電式遮光筒型輝度計の諸特性
}

\author{
正会員 坊 博 ${ }^{*}$ 専門会員 竹 山 説 三*

\section{The Characteristics of a Photo-Electric Baffle Tube Type Brightness Meter} \\ by Hiroshi Bō (Member) and Setsuzo Takeyama (Fellow Member) \\ (Faculty of Engineering, Ōsaka University)
}

\begin{abstract}
The characteristics of a brightness meter having a baffle tube, i.e., directional sensitivity and scanning field angle, have been investigated theoretically and experimentally. Especially, the design of the baffle tube has been treated theoretically and the characteristics of the directional sensitivity, compared with the experimental results.

The relation between the source size and the aperture scanning anglel of the instrument has been considered with the directional sensitivity and also the accuracy of this instrument has been discussed.
\end{abstract}

\section{緒面}

光電式輝度計を大別すれば，レンズ系を用いるものと

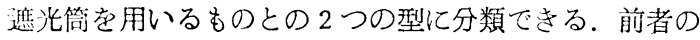
型については既に商品化されているものもあり，後者の 型については既にその試作報告があるが(1)，乙の場合の 遮光筒の諸性質については未だ十分検討されていないの で，ここではこれらの点に検討を加え遮光筒型輝度計の 諸特性な理論的ならびに実験的に明らかにした。

\section{1 遮光筒型輝度計の構造}

为 1 図のような 面 $\mathrm{S} の \theta$ 方向の輝 度を一様な輝度 $B$ とすれば， p 点に 打ける法線照度 $E_{n}$ は

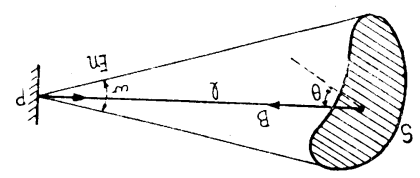

为1图短度計の原理

$$
\begin{aligned}
& E_{n}=B S \cos \theta / l^{2}=B \omega \\
& \text { ただし } l \text { は } P \text { 点と面との距離 } \\
& S \text { は光源の面積 }
\end{aligned}
$$

となり, 照度 $E_{n}$ は立体角 $\omega$ を一定とすれば輝度 $B$ に 比例する。した がって, 一定の 立体角を为 2 図 のような遮光筒 により規制して

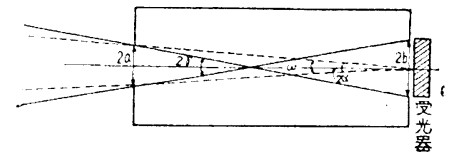

\footnotetext{
*大阪大学工学部
}

受光器に取付けれ法, その振れは輝度 $B$ に比例すること になる。しかし，実際には受光面は点ではなくある面積 をもつ加ら, 遮光筒で立体角を制限しても, 受光面上の各 点では立体角は少し異なる。また，为了図のように遮光 筒の軸に対し， $\theta$ なる角 で入射した平行光線は受 光面へは全光量が到達で きず，例えば，開口部， 受光部が同一值径の円形 であるとすれば，为 3 圈 の斜線の部分のみが入射 するととになるため，入 射方向により感度が異る ことになる。したがっ て, 遮光簡を用いる輝度 計に辌いては办かる方向 感度特性があるととも に，その他僬光筒内部の

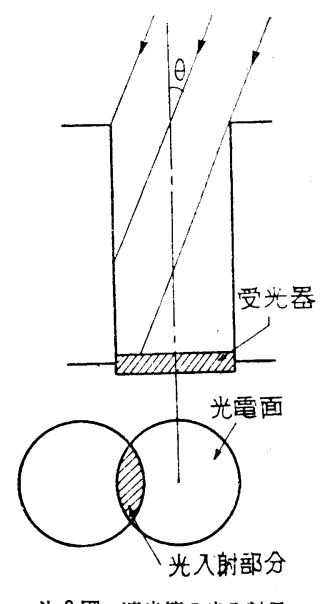

为 3 図腎光䇠の光入射罯 反射光にもとずく誤差も考光㸚ばならない。

\section{2 遮光筒の設計}

\section{1 開口角（見込角）の定義}

为 2 図に招いて受光面の中心 $P$ 点が開口面を見込导立 体角は

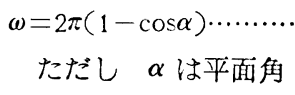

であたえられる.しかし，実際に受光面に入ってくる光 
線は, 第 2 図の平面角で $2 \gamma$ 内のものであるため, ここ では開口角としてとの ち, 为 2 図のような開口部の直径 $2 a$, 受光部の直径 $2 b$ なる場合の遮光筒の開口角としては

$$
\gamma=\tan ^{-1}(a+b) / L
$$

となる。

$$
\begin{array}{r}
\text { いま } a=b \text { とすれ澕 } \\
\gamma=\tan ^{-1} 2 a / L \cdots . . .
\end{array}
$$

となる。

\section{2 遮光筒の設計}

为 4 図のように, 閒口角 $\gamma$ 外の光源 $B$ 加らの光が迤 光筒内面塹で反 射して受光面に 到達するから， 筒の内照虫十分 低反射率になる

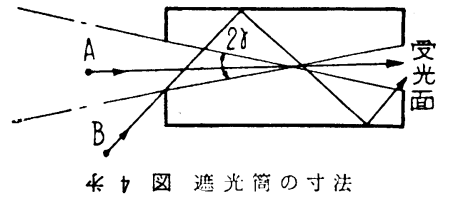

ように注意しなければならない。しかし，低反射率にな るよう注意しても十分な絬果が得られない場合が多いの で, 普通筒の中間に baffle を挿入してとの影響を除く.

次に baffle 1 枚を簡の中央に設けて使用する場合, 遮光筒の各部の寸法を検討する.

簡単のため为 5 図のように開口部と受光部の直径を等 しく $2 a$, baffle の穴の直径を $2 c$ とする. 始めに開口 争 $\gamma$ が与兄られたとすれば，筒の長さ $L$ は(4)式より

$$
L=2 a \tan \gamma
$$

となる、また，遮 光筒の直径を $2 d$ とし, 为 5 図のA $\mathrm{B}$ 打よび $\mathrm{A}^{\prime} \mathrm{B}^{\prime}$ 面 よりの受光部に入 射しないようにす

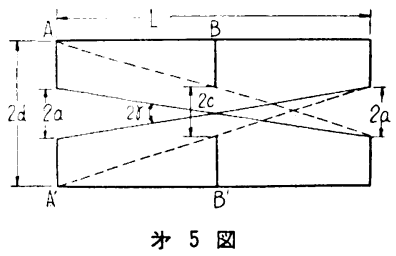
るためには, baffle の直径 $2 c$ は

$$
d: a+2 c
$$

なる関係式を満足しなければならないことがわかる。い ま，簡単のため $c=k a$ (ただし $k \geqq 1$ とす）とすれば

$$
d \geqq a(1+2 k)
$$

となり, 筒の半径 $d$, 開口部の半径 $a$, baffle の半径 $c$ との間の関係式が得られる. 例えば, $k=2$ とすれば

$$
d \geqq 5 a
$$

なる関係が成立すればよいことになる。

同様な方法で bafflle が $\mathrm{n}$ 枚ある場会も $d$ と $a$ との関 係が得られるが，ここでは省略する。

試作遮光简例

開口角 $\gamma=6^{\circ}$

開口の直径 $2 a=3 \mathrm{~mm}$

bafflle の值径 $k=2$ として $2 c=6 \mathrm{~mm}$

筒の長さ $L=28.6 \mathrm{~mm}$
筒の百径 $2 d=20 \mathrm{~mm}$

の遮光筒を視感度

補正した 2 次電子 增加管に为 6 図の ように構成して付 した.との場而の 運光筒の特性を次 に述べる。

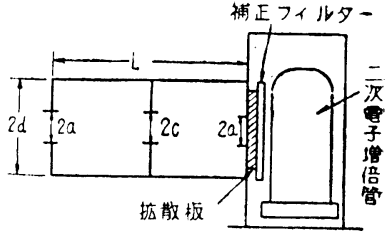

为 6 図

\section{3 遮光筒の方向感度特性}

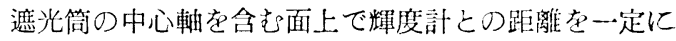
保って点光源を移 動させ,その筒の 中心軸と角 $\theta$ をな す場合の光電流 $i \theta$ を測定し, $\theta=00$ ときとの比, す なわち $i_{\theta} / i_{0}=k(\theta)$ を为 7 図に示持.

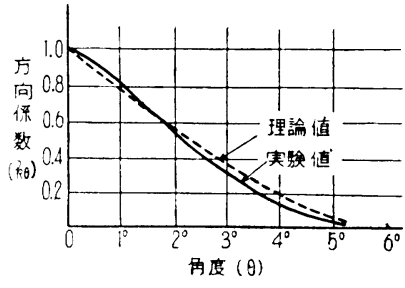

为 7 图 万向感度特性 この感度の方向特性老理論的に求めると, 今平行線が遮 光简の軸と $\theta$ をな して入射する場合 光束は次のように なる。为 8 図のよ うに開口部受光部 の半径をそれぞれ $a, b$ とすれば光

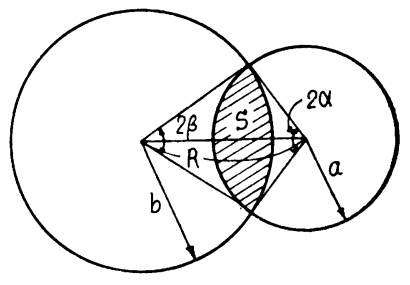
の入射する斜線の面積は

$$
S=a^{2} \alpha+b^{2} \beta-\frac{1}{2} a^{2} \sin 2 \alpha-\frac{1}{2} b^{2} \sin 2 \beta .
$$

となる. 一方

$$
\begin{aligned}
& \alpha=\cos ^{-1}\left(R^{2}+a^{2}-b^{2} / 2 a R\right) \\
& \beta=\cos ^{-1}\left(R^{2}-a^{2}+b^{2} / 2 b R\right) \\
& R=(a+b) \tan \theta / \tan \gamma \cdots \ldots \ldots \ldots
\end{aligned}
$$

であるから, 光束 $L(\theta)$ はその面积 $S$ に比例するから $L_{(\theta)} \propto\left\{\left(a^{2} \cos ^{-1} 1-\{(a+b) \tan \theta / \tan \gamma+(a-b) \tan \gamma / \tan \theta\}\right.\right.$ $+b^{2} \cos ^{-1} \frac{1}{2 b}\{(a+b) \tan \theta / \tan \gamma-(a-b) \tan \gamma / \tan \theta\}$ $-\frac{1}{2} a^{2} \sin 2 \cos ^{-1} \frac{1}{2 a}\{(a+b) \tan \theta / \tan \gamma+(a-b) \tan \gamma / \tan \theta\}$ $-\frac{1}{2} b^{2} \sin 2 \cos ^{-1} \frac{1}{2 b}\{(a+b) \tan \theta / \tan \gamma$ $-(a-b) \tan \gamma / \tan \theta\} \cos \theta$

となる. 今 $a=b$ とすれば

$$
\begin{aligned}
& L_{(\theta)} \propto 2 a^{2}\left\{\cos ^{-1}(\tan \theta / \tan \gamma)\right. \\
& \left.-\frac{1}{2} \sin 2 \cos ^{-1}(\tan \theta / \tan \gamma)\right\} \cos \theta
\end{aligned}
$$


したがって，方向係数 $k(\theta)=L(\theta) / L(\theta)$ は

$$
\begin{aligned}
k(\theta)= & \frac{2}{\pi}\left\{\cos ^{-1}(\tan \theta / \tan \gamma)\right. \\
& \left.-\frac{1}{2} \sin 2 \cdot \cos ^{-1}(\tan \theta / \tan \gamma)\right\} \cos \theta
\end{aligned}
$$

为 7 図は $\gamma=6^{\circ}$ の場合の $k(\theta)$ と $\theta$ との関係を示す.

\section{4 遮光筒の視野角}

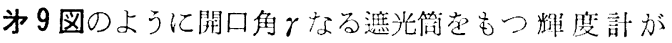
円形の等輝度抎散板 $\mathrm{D}$ より距離 $R_{1}, R_{2}$ にあるとすれ ば, $R_{1}$ の位 置ては円形㹡 散板の一部 分のみを見込 光ととになる が, 距離が遠 くなるにした が、，その見

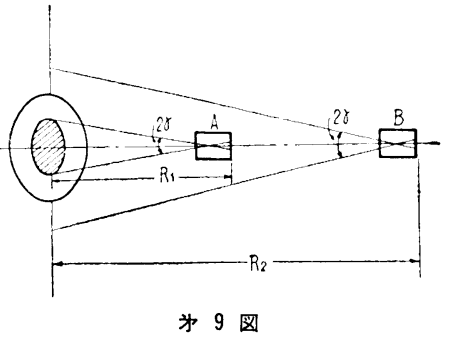

込む部分が增加し, 遂には距離 $R_{2}$ の位置のように, 拡 散円板以外の部分 を見込むことにな り, 辉度計の振れ は減少することに なる、いま，実験 で輝度一様な直径 $3 \mathrm{~cm}$ の昖散性円板 よりの距济を变化

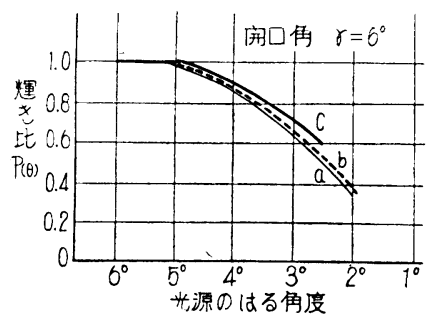
させた場合の輝度計の振れの相対值を为10図に示す。す なわち，ある一定 の距離までは振れ は一定であるが, それ以上になれば 次第に減少する. いま, 乙の関係を 理諭的に検討し

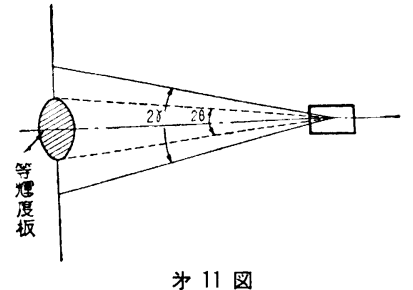

て見ると，为11図のような関係位置で，光源たる円板が $\mathrm{p}$ 点にはる角 $2 \theta$ が輝度計の開口角 $2 \gamma$ より小なる場合 と, $2 \theta$ が $2 \gamma$ に等しい場合との比 $p(\theta)$ をとれば

$$
p(\theta)=\int_{0}^{\theta} k(\theta) \sin \theta \cdot d \theta / \int_{0}^{\gamma} k(\theta) \sin \theta \cdot d \theta
$$

ただし， $k(\theta)$ は遮光筒の方向感度係数となる.

いま， $\gamma=6^{\circ}$ として,(15)式より計算した $p(\theta)$ を为10図の (b)曲線に示す。亦た, 第 7 図の実験曲線より求めた $p(\theta)$ を为10図の (c) 曲線で示す, 大体, これらの理諭計算值 と実測值は一致しているが少し異なっている，てれは実 験上の誤差であろうが，正確に開口角が設計通りになっ
ていないととによる影響も多大にあると考光られる。

\section{5 受光部の構成および特性}

受光部は前述の 通り, 2 次電子增 倍管老使用したも ので，これに视感 度補正のためのフ ィルタを使用し ている。为12図に

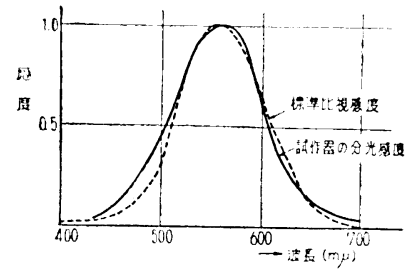
この分光感 度を示して いる.また， 光電流增幅 回路は为 13

図のような 差動直流增 幅器を用い て行ない, その輝度と 振れと関係 は, 为14図 のような直 線関係が得 られてい る.
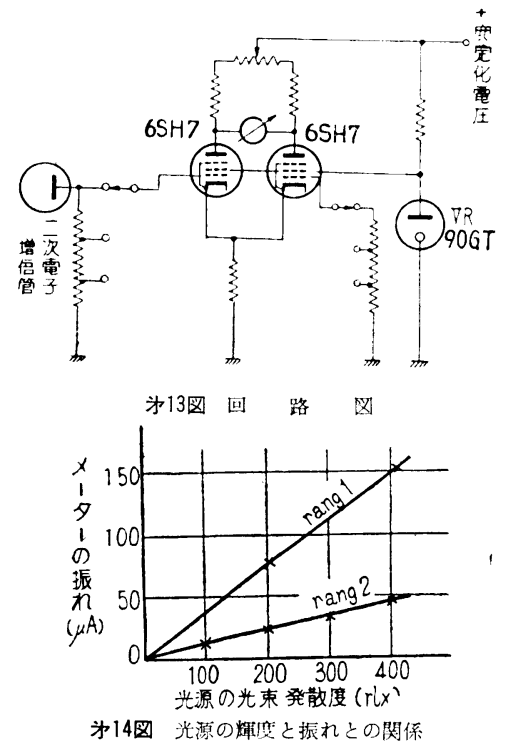

\section{6 実際使用上の注意}

遮光筒型輝度計は上述のような諸特性を有しているこ とが理論的, ならびに実験的にも判明した。したがっ て, これら特性を十分理解して使用せ称ば測定に誤差を 生ずるととになる.

まず䛊差の原因として

1. 輝度計自身にもとづくもの

(a) 分光感度の視感度補正が十分精確に行なわれて 扔らず，その䛊差にもとづくもの。

(b) 電子管の不安定，扰よび劣化にもとづくもの.

(c) 受光面に扔ける cosine law よりのずれにもと づくもの.

2. 使用上にもとつうくもの

(a) 輝度計の開口角より被测定面がはる角の方が小 さくなるために拓てる犃差

(b) 被測定面を正確に輝度計が見込まないことに上 るもの

(c) 被測定面の輝度が一様でない場合によるもの 訨が考えられる。との中(1)によるものは輝度計作製時に 
注意すれば除きうるものであるか, (2)のものは先に視野 角のところで述べた理由によるもので，十分注意せねば ならない.これは特に距離の遠い所にあるものを測定す る場合注意せるねばならない, したがって, 遮光筒輝度計 は近距離で使用する場合, または光源面の大なるものの 一部分の等輝度面を測定するようなときには, 正確に湘 定できるととになるが，遠距離小面積の光源の測定は注 意を要するととになる。

\section{結言}

遮光筒を用いた輝度計の諸特性, すなわら方向感度特 性, 扎よび視野角の特性を理論的,ならびに実験的に求 めるとともに, 遮光筒の寸法決定法を明らかにするとと ができた、すなわち，筒の径 $d$ と開口部の径 $a$, baffle の径 $c$ 間には

\section{$d \geqq a+2 c$}

を満足せねばならないととが見出された。

また, 遮光筒の開口角の定義を明らかにして, それと 各種特性との関係式も導き出したが, 実験的にはこの開 口角は正確には決定できないとと, 打よび視野角の特性 より使用上注意しなければ誤差の原因となる点を明らか にするとともに, 近距離ではかかる誤差は比較的扔こ、り がたい等その使用上の誤差等についても検討した.

最後に本研究に当り, 協力して頂いた岡田浩雄君をは じめ研究室の諸兄に感謝する次第である.

(受付, 35-10-10)

\section{文献}

(1) Y.G. Hurd : I. E. 41 (1946) 306

C. A. Horton : I. E. 45 (1950) 458 竹山, 坊, 喜多村: 電気三学会为 26 回園連大 7 . 13(昭27.5)

\section{新製品紹介}

\section{耐压防爆型水銀灯器具}

1. 名称 $\mathrm{ZH}$ 型耐圧防爆型水銀灯器具

2. 特長

(1) 本器具は学働省産業安全研究所工場電気設備防爆 指針に合致すると同時に同研究所の爆発試験に合格 したものである。

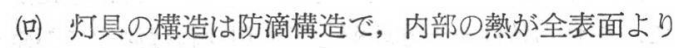
均一に放散するようになっている。

(1) 灯具材料には而蝕性が良好で, 機械的強度が優

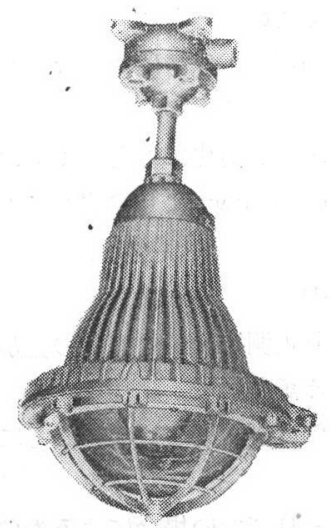

2H-400(400W用)

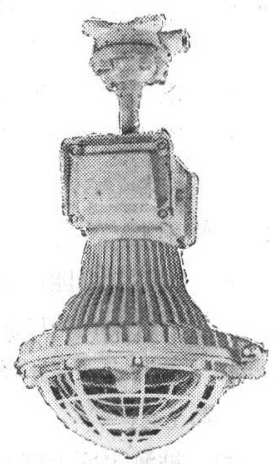

ZHI-100(100W用)
れ，その上重量の軽い ヒドロナリューム合金 を使用している。

$\Leftrightarrow$ グローブは硬質ガラ 又支使用, 内部の爆発 と外部の機械的強度に 十分耐え得る厚みを有 している.

(木) ソケットは耐震構造 のものを使用, ソケッ 卜支持金具は光源の大

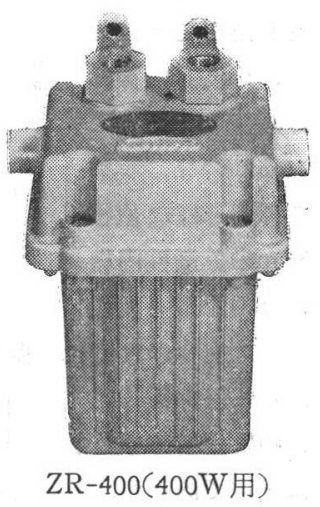
きさに応じ上下に移動でさる.

( ラ）ンフの交換は硝子グローブを緩めるととなく， その保持枠締付ボールトを緩めるだけで蝶番式にて 簡単に行なうことができる。

3. 使用場所 防爆指針の第 1 種危険場所

4. 製作者名 星和電機株式会社

5. 価格 ZHI-100 (100ワット用) 47,000.— ZH-400（ZR-400を含む） 67,500.何れもランプバラスト込の価格である.
250 ワットの場合
64, 000.-
300
65,500 . - 